\title{
Simulating Land-use Change in a Regional Planning Context
}

\author{
Eric Koomen • Arjen Koekoek • Egbert Dijk
}

Received: 1 September 2009 / Accepted: 27 April 2010 /

Published online: 26 May 2010

(C) The Author(s) 2010. This article is published with open access at Springerlink.com

\begin{abstract}
Land-use simulation can provide important information to regional spatial planning. This paper introduces the application of a detailed land-use model in different phases of the development of a Regional Spatial Strategy for the Dutch province of Overijssel. After introducing the planning and modelling context it first discusses an exploratory study that used potential future land-use configurations according to trend-based scenarios and specific policy objectives. Part of this study focused on visualising potential spatial developments according to three different spatial policy ambitions related to: water management; safety and health; and compact urbanisation. These depictions of policy alternatives were used to help formulate the Regional Spatial Strategy. In the subsequent Strategic Environmental Assessment land-use simulations were used to help assess the potential sustainability impacts of the proposed new set of spatial policies in relation to the current spatial policies. Based on these subsequent model applications the merits of the applied modelling approach are discussed. In addition, we pay attention to several more general issues related to the simulation of land-use changes in support of regional spatial planning. These issues relate to the treatment of uncertainty, the confidence that can be placed in the potential impact of planning initiatives and the need for integrated data infrastructures.
\end{abstract}

E. Koomen $(\bowtie) \cdot$ A. Koekoek

Geodan Next, President Kennedylaan 1, 1079 MB Amsterdam, The Netherlands

e-mail: ekoomen@feweb.vu.nl

E. Koomen

Department of Spatial Economics/SPINlab, Vrije Universiteit Amsterdam, De Boelelaan 1105,

1081 HV Amsterdam, The Netherlands

E. Dijk

Province of Overijssel, PO Box 10078, 8000 GB Zwolle, The Netherlands 
Keywords Regional planning · Strategic Environmental Assessment ·

Land-use simulation · Planning support

\section{Introduction}

Many geo-information tools appear to be rarely used for typical planning tasks, such as visioning, storytelling, forecasting, analysis, sketching and evaluation of policy alternatives (Vonk et al. 2005). Apart from basic activities, such as performing spatial queries and generating thematic maps, the progress in the application of such tools to help solve key planning problems remains very limited as is documented in the wealth of literature on planning support systems (Carsjens 2009; Geertman and Stillwell 2009; Stillwell et al. 1999; Vonk et al. 2005). This paper focuses on the application of a specific type of geo-information tools - spatially explicit land-use models - that have the ability to assist in many planning-specific tasks as recent overviews document (Koomen et al. 2007; Mudgal et al. 2008; Veldkamp and Verburg 2004). Simulations of land-use change can provide important input to studies related to the preparation, development and, to a lesser extent, evaluation of large-scale spatial plans and strategies (Koomen et al. 2008c). In the preparation phase of spatial planning, land-use models are typically applied to sketch potential spatial developments using trend analysis or a scenario-based approach (Borsboomvan Beurden et al. 2007; e.g. Geoghegan et al. 2004; Verburg et al. 2006). Alternatively, optimisation of land-use patterns according to specific constraints and policy objectives can be performed to generate alternative solutions to spatial problems (e.g. Loonen et al. 2007). In the subsequent development phase land-use models can be applied to assess the potential land-use related impacts of proposed policy alternatives (Sheridan et al. 2007; Van Meijl et al. 2006).

This paper demonstrates the application of a land-use model in an actual regional planning context for the province of Overijssel in the east of the Netherlands. Applying land-use simulation on a regional scale in close cooperation with a regional authority to contribute to the policy formulation process is an important step forward in the application of land-use models as it involves knowledge transfer from academic research to actual planning practice. The paper discusses the application of a land-use model in the preparation and subsequent development phase of a new Regional Spatial Strategy in which the simulation of land-use patterns is a crucial component. It is organised as follows: "Planning and Modelling Context" sketches the spatial planning context of the model applications and provides a short introduction to the applied model. "Spatial Exploration: Overijssel in 2040" discusses an exploratory study that provided potential future land-use configurations according to trend-based scenarios and specific policy objectives. The results of this study were used in the policy formulation process for the Regional Spatial Strategy. "Strategic Environmental Assessment" describes the completion of an Environmental Impact Assessment related to the Regional Spatial Strategy. Both sections focus on the role of the applied model in the planning process. The final section discusses the merits of the applied modelling approach and finishes with some more general comments related to the simulation of land-use changes in support of regional spatial planning. 


\section{Planning and Modelling Context}

\section{A New Regional Spatial Strategy for Overijssel}

The new national Spatial Planning Act introduced in 2008 calls for a more pro-active role of Dutch provinces (regional administrations) in the policy arena. In fact, it demands the definition of Regional Spatial Strategies that are new in process, content and legal status. These Strategies are the main guiding documents in spatial planning at the regional and local level and typically focus on the year 2020 with a further outlook on additional developments until 2040. To draft such Strategies two questions need to be answered: what regional spatial developments can be expected in the future?; and what role can regional policy making play to direct such developments? Land-use simulation can help solve these questions.

In 2008, a number of provinces defined their Regional Spatial Strategies by creating an outlook on possible spatial developments until 2040 using land-use simulations (Atzema et al. 2008; Koomen et al. 2008a; Kuijpers-Linde et al. 2008). For two provinces these depictions of autonomous spatial developments were supplemented with studies on possible spatial implications of new policy alternatives. These studies not only showed the task at hand for these provinces, but also explored possible solutions for these tasks. In this paper we focus on the case of Overijssel where land-use simulations were also used in the subsequent Strategic Environmental Assessment. This case is especially interesting as it shows the potential of land-use modelling in subsequent phases of the planning process (problem recognition, generation of policy proposals and evaluating their impacts) using different simulation methods (trend-based simulation, optimisation, and impact assessment). For a more in-depth treatment of these phases in the planning process and the different simulation methods that are typically associated with them the reader is referred to other publications (Koomen et al. 2008c; Vedung 1997).

Overijssel decided to adjust their prevailing strategic plans for the physical environment in 2008. The need for a new strategic plan was especially prominent with the emergence of new themes on the policy agenda such as climate change and new insights in demographic developments. Climate change is a relatively new theme in spatial planning (Kabat et al. 2005; Van Leeuwen et al. 2009) and relates in this case foremost to sea level rise, increased river discharge and more frequent excessive rainfall causing a series of water management issues. The province used this new plan to introduce a new planning creed referred to as 'steering on quality'. The introduction of the new national spatial planning act provided a good opportunity to redefine the provincial aims and embed these in spatial plans. For this reason the provincial council decided to develop a new and integrated strategy for the physical environment. This plan, the Regional Spatial Strategy (Omgevingsvisie Overijssel) replaced five individual plans and functions as spatial structural vision, regional water management plan, environmental policy plan, provincial transport plan and soil plan. The sustainability and spatial quality objectives in the Strategy act as overarching perspectives that connect the spatial themes in the plan.

At the start of the policy formulation process, the province of Overijssel wanted to explore different options for new spatial policies. In this process, important questions were posed: to what degree are current spatial developments 'climate 
proof', and what are the impacts of possible spatial policies? The applied land-use model helped answering these questions by simulating policy-specific future landuse configurations at different stages in the development process. From the start of the project the specific assumptions associated with this type of research were shared with the representatives of the province. As many future developments contain a high degree of uncertainty, especially on the longer term, the provided simulations should be seen as possible future land-use configurations and not as blueprints for the future. They were used to stimulate thinking about cause-effect relationships in relevant policy discussions. The applied land-use model thus helped to transform academic knowledge on spatial processes and uncertainty to planning practice.

\section{Introducing the Land Use Scanner Model}

Land-use change models can be defined as tools to support the analysis of the causes and consequences of land-use change (Verburg et al. 2004). They can help formulate adequate spatial policies by simulating potential autonomous spatial developments or, perhaps more importantly, by showing the possible consequences of different policy alternatives. Model simulations are thus able to confront policy makers with a context of future conditions and an indication of the impact the spatially relevant policies they propose. The many books, special issues and review papers dedicated to land-use models show a very heterogeneous group of instruments with considerable differences regarding their background, starting points, range of applications et cetera (Agarwal et al. 2002; Koomen and Stillwell 2007; Parker et al. 2003; Pontius et al. 2008; Verburg et al. 2006). Models can, for example, be static or dynamic, focus on transformation or allocation of land use, emphasise land use or land users, apply a probabilistic or deterministic approach, provide an integrated or sector-specific outlook and represent space in grids or zones (Koomen and Stillwell 2007). They furthermore rely on a wide range of theories and methods that are linked to different scientific disciplines such as economics, geography and mathematics.

The Land Use Scanner applied here, has its roots in economics and initially applied a logit-type approach based on discrete choice theory to simulate the probability that a location is selected for a certain use (Hilferink and Rietveld 1999). It is an integrated land-use model that offers a view of all types of land use, dealing with urban, natural and agricultural functions. It has been developed in 1997 by a group of research institutes (www.lumos.info), and has since then been applied in a large number of policy-related research projects in the Netherlands and abroad. The model's basics and recent calibration have been described extensively elsewhere (Koomen et al. 2008b; Loonen and Koomen 2009). The model is well-suited to perform what-if type of applications to visualise the spatial developments associated with specified conditions. In that respect it is comparable to well-known rulebased simulation models such as the original California Urban Futures (CUF) model and the What If? system (Klosterman 1999; Landis 1994). Especially in the context of strategic, scenario-based national planning, the model proved to be a valuable tool to inform policy makers about potential future developments (Borsboom-van Beurden et al. 2007; Dekkers and Koomen 2007; Koomen et al. 
2005; Schotten et al. 2001b) or to provide ex-ante evaluations of policy alternatives (Scholten et al. 1999; Van der Hoeven et al. 2009). More recently the model has also been applied to optimise projected spatial developments according to specific policy objectives (PBL 2010). Such land-use simulations have the potential to inform policymakers about alternative solutions for current spatial problems. An English language overview of recent Dutch applications is available soon (Borsboom-van Beurden and Koomen 2010), whereas applications in several other European countries are documented in a range of papers (Hoymann 2010; Schotten et al. 2001a; Wagtendonk et al. 2001).

The model, essentially, balances the demand and supply of land using three main components:

- external regional projections of land-use change, usually referred to as demand or claims, that are land-use type specific and can be derived from, for example, sector-specific models of specialised institutes;

- a local (cell-based) definition of suitability that incorporates a large number of spatial datasets referring to current land use, physical properties, operative policies and market forces generally expressed in distance relations to nearby land-use functions;

- an algorithm that allocates equal units of land (cells) to those land-use types that have the highest suitability, taking into account the regional land-use claim. This discrete allocation problem is solved through a form of linear programming (Loonen and Koomen 2009).

A completely new version of the Dutch Land Use Scanner model, offering the possibility to use a grid of $100 \times 100 \mathrm{~m}$, became available in 2005 . It covers the terrestrial Netherlands in about 3.3 million cells. This resolution comes close to the size of actual building blocks and allows for the use of homogenous cells that only describe the dominant land use. The previous version of the model had a $500 \mathrm{~m}$ resolution with heterogeneous cells, each describing the relative proportion of all present land-use types. Together with the introduction of homogenous cells that represent a single, dominant land use, a new algorithm has been developed that finds the optimal allocation of land use given the specified demand and suitability definition (Koomen et al. 2008b). The increased spatial resolution also makes it possible to consider applications on a regional scale, but prior to the study described in the paper this has only been performed in one study so far (Borsboom-van Beurden et al. 2007).

The model is comparatively static and normally uses a limited number of intermediate time steps to simulate a final year. In the current application two intermediate time steps (2010 and 2020) are used to simulate developments in the 2000-2040 period. This means that model results only contain a limited degree of path dependency and associated emergent properties. The model is thus not wellequipped to simulate dynamic natural processes such as vegetation succession. This is not considered a problem in the Netherlands where urbanisation and nature development processes dominate that typically follow lengthy planning processes that can take decades. The advantage of this lack of dynamics is that the model is extremely flexible and fast. To create a model version that is able to simulate the natural processes typical of the more remote, rural parts of Europe the model is 
currently being combined with the well-known dyna-CLUE model (Verburg et al. 2008; Verburg and Overmars 2007).

In the Dutch modelling context global and national socio-economic scenarios are initially downscaled to the regional level by means of sector-specific models (Borsboom-van Beurden et al. 2007). Such models provide future projections of, for example, residential, commercial or agricultural development according to the best available methodological approaches, data sets and assumptions. The Land Use Scanner then integrates these sector-specific outlooks and downscales them to the level of individual pixels. This application of state of the art sector-specific models comes at the cost of potential inconsistencies in underlying initial conditions, scenario-based-assumptions and a more general lack of feedback between sectorspecific developments (Dekkers and Koomen 2006). The incorporation of such feedbacks would, for example, allow a more integrated assessment of the relation between residential and commercial development. Current model improvements focus on establishing a more direct link between the sector-specific input models. In addition research is underway to address the issue of multifunctional land use that is notoriously difficult to incorporate in most land-use models (Verburg et al. 2009).

\section{Spatial Exploration: Overijssel in 2040}

\section{Creating Regionalised Trend-based Simulations of Future Land Use}

Starting point for the spatial exploration of Overijssel was the Second Sustainability Outlook study carried out by the Netherlands Environmental Assessment Agency (PBL 2010). This national study aims to show an optimal allocation of land-use types according to several sustainability criteria. It describes two trend-based simulations of future land use that aim to show probable spatial developments based on past developments and current (local and national) plans and policies. The two simulations differ, however, in the amount of urban change that is expected: following a moderate and high growth scenario respectively. These growth rates correspond to the Transatlantic Market and Global Economy scenario described in the Welfare, Prosperity and Quality of the living environment study of the Dutch assessment agencies (CPB et al. 2006). The related scenario assumptions are only used to assess the potential diversity in the demand for residential and commercial land. The demand for the other types of land and the spatial relations embedded in the suitability maps for all land-use types are the same for both scenarios and reflect current trends and spatial policies. An important assumption in both scenarios in relation to the province of Overijssel is that the influx of citizens from the Randstad is limited compared to directly adjacent provinces such as Gelderland, NoordBrabant and Flevoland.

In order to apply the national Land Use Scanner application developed for the Second Sustainability Outlook to the specific context of Overijssel, several adjustments were necessary. In close cooperation with various representatives of the province, local suitability variables were adjusted to better match current regional spatial policies. This feedback was organised through a number of workshops in which provincial policy makers reacted on intermediate results. Their local 
knowledge allowed an iterative fine-tuning of the simulation. The most important changes resulting from this feedback process were:

- The importance of the national concentration areas (bundelingsgebieden) for residential and commercial development was decreased, as this national policy was not considered to be of great importance by the representatives of the province;

- Areas close to the larger cities were considered likely locations for residential and commercial developments. This applied only to a selection of eight relatively large towns. This measure was implemented to limit the growth of smaller towns that was observed in the initial national simulations and that was considered not to be in line with current regional policies that aim to concentrate urbanisation;

- Commercial areas from the IBIS-database (a national inventory of to be developed business locations created by Arcadis and Stec Groep 2007) were considered attractive for new commercial development;

- New developments in flood-prone areas and water-retention areas were discouraged as these are not in line with current and proposed restrictive policies;

- A spatial redefinition of the National Ecological Network ${ }^{1}$ replaced an older version. New commercial and residential functions in the Network and the designated National Landscapes ${ }^{2}$ were considered unlikely and received a higher negative suitability factor.

The above changes were incorporated into the suitability maps that describe the preferred locations for the different types of land use. Restrictions resulted in lower or even negative land-use suitability values, whereas stimulating policies were reflected as higher suitability values. The strengths of these policies, and thus their weights in the suitability maps, were defined in close cooperation with the policy makers and thus reflect their expert judgement and that of the modellers. Application of the changed suitability values resulted in adjusted spatial patterns for Overijssel in the year 2040 .

The province of Overijssel was, furthermore, interested in the spatial impact of the trend-based scenario simulations on certain sensitive areas. The impact of urbanisation was analysed in relation to three types of areas, characteristic of different policy themes. The rationale for these impact assessments was the following: from a nature perspective, built-up developments in the National Ecological Network are discouraged; for landscape conservation, large-scale developments in the National Landscapes are discouraged; and to reduce flood risk, building in flood-prone areas is unwanted. The impacts were assessed by making a pixel-by-pixel comparison between the urban (residential, commercial and greenhouse) locations in the maps showing current and simulated land use. This straightforward raster overlay operation subtracted the binary map with simulated urban areas from the binary map with current urban areas, resulting

\footnotetext{
${ }^{1}$ The National Ecological Network is a master plan for a spatially coherent set of nature areas. The national delineation of this network is refined by the provinces to implement it in the planning process. An extensive discussion and international comparison of this planning concept is provided elsewhere (Jongman et al. 2004)

${ }^{2}$ National Landscapes are primarily agricultural areas with significant landscape values and planning controls comparable to the British Areas of Outstanding Natural Beauty. A more detailed description of this planning concept and a comparison with the National Ecological Network is provided elsewhere (de Jong 2009).
} 
in a map with three values: 1 (new urban), 0 (no change) and -1 (loss of urban). The thus obtained new urban locations were then overlaid on maps representing the specific policy themes. This procedure showed that new urban development in nature areas and National Landscapes is limited in the two trend-based scenarios, while such development is more abundant within flood-prone areas, especially near the larger cities of Zwolle and Deventer. Especially in the high pressure trend scenario, the amount of urban development in the risk-prone areas is substantial.

\section{Visualising Theme-specific Spatial Policy Alternatives}

What spatial developments can be expected if one thematic ambition is taken as the leading objective in spatial planning? By putting one policy objective central in the land-use simulations, the spatial impact of a successful implementation of this specific policy can be shown. The province was interested in the potential spatial developments related to three separate sets of spatial policy ambitions. The ambitions were formulated as coherent sets of spatial policies related to the themes of: 1) water management; 2) safety and health; and 3) compact urbanisation. The high spatial pressure scenario was used for these simulations, because it maps the impact of the policy measures more clearly. As such, it prepared policy makers for a worst-case scenario with respect to the spatial developments that had to be accommodated in the policy alternatives. The adjusted regional model application described in the preceding section was used for this optimisation effort. In fact, the model adjustment and definition of policy alternatives were performed simultaneously as part of a series of workshops. During these interactive sessions with provincial policy makers the key characteristics of the policy alternatives were defined, their implementation in the model was discussed and preliminary simulation results were evaluated. This process led to the addition of many different datasets describing the stimulating or restricting policies associated with the policy alternatives to create diverging suitability maps for the three policy alternatives. The alternatives were, however, not defined in isolation: they shared the same demand for land and had a common basis for the definition of suitable locations. They emphasised different policy objectives to show the potential resulting developments to an extent that is not exactly likely to happen in reality. This over emphasis had the advantage of presenting a clear image of potential positive or negative impacts of proposed policies. By comparing the simulation results of the trend-based scenario $(T)$ and the theme-specific policy alternatives $\left(A_{1,2,3}\right)$ spatial differences were visualised, as is depicted in the flowchart (Fig. 1).

A first thematic policy alternative comprised the optimisation of spatial developments from a water management perspective. Several policies were included here. To prevent drought, groundwater protection areas are kept free from urban development. To limit the potential impact of flooding, urban development is not allowed within flood-prone areas, near the major waterways, or in areas with high inundation risks, such as river flood plains. Compared with the trend-based scenario, this implies a shift in developments from the lower lying cities in the west of the province to cities and villages situated on slightly higher grounds in the north and east of the province.

A second thematic policy alternative put health and safety of the inhabitants first in the selection of new urban development areas. Residential developments were 


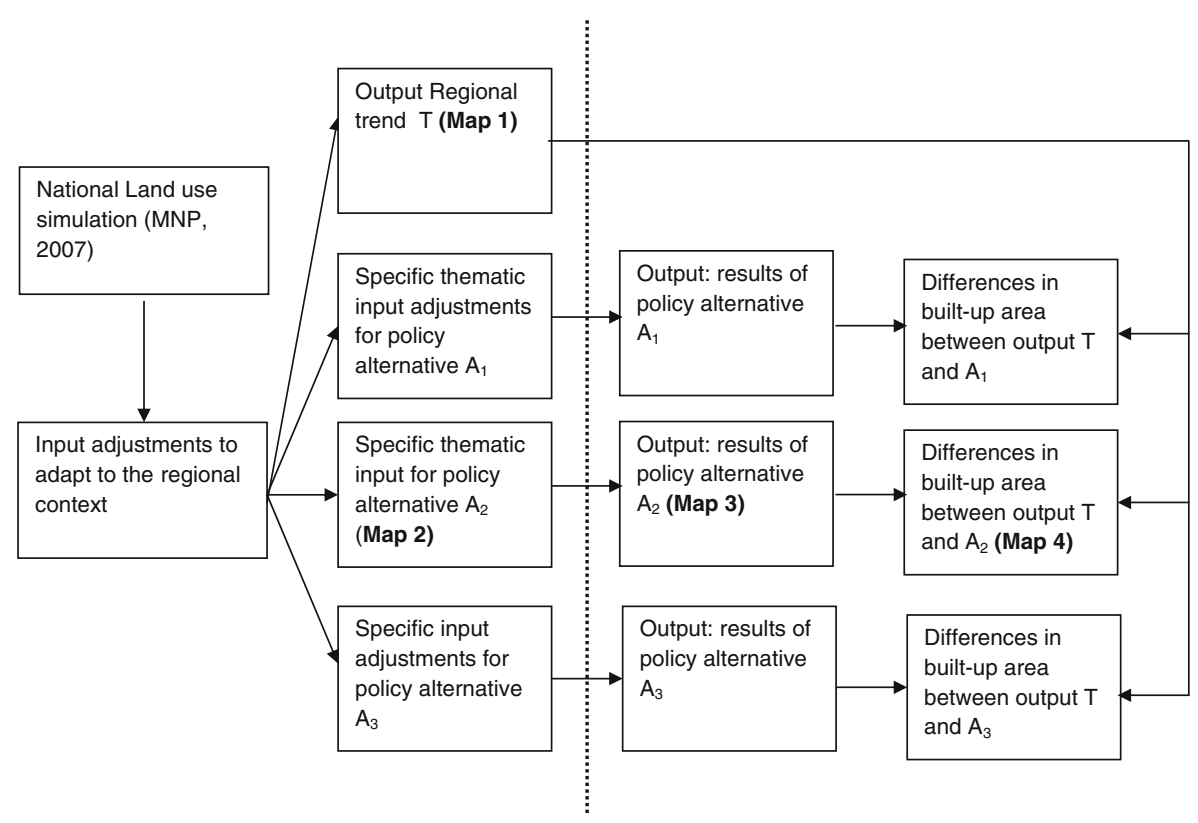

Fig. 1 Flowchart describing the creation of regionalised policy-specific land-use simulations for the water management (A1), health and safety (A2) and urban containment (A3) alternatives. The mentioned maps 1 to 4 are included in Fig. 2

thus banned from areas with high levels of noise disturbance and personal safety risk (e.g. near dangerous plants, dangerous goods transportation routes, gas lines or high voltage lines). Figure 2 shows the development of this specific policy alternative and compares its distribution of urban areas with the trend-based scenario. Crucial in this alternative were the areas with safety and health restrictions that are safeguarded from new developments by adding negative suitability factors. The resulting maps showed that developments near major roads come to a halt, leading to increased urban development near some smaller cities. Above all, however, the analysis showed that enough alternative urbanisation locations are available to implement this extensive set of environmental policies.

A third thematic policy alternative focussed on different urbanisation strategies. One policy strategy spread the residential development among more and smaller cities. Another strategy centred residential developments around the largest cities in the province.

In short, this study revealed that the projected urbanisation patterns may locally impact landscape quality, personal safety and water management. Developments in the west of the province require specific attention regarding climate adaptation (especially flood risk management). The province used the spatial exploration to frame the possible effects of new building developments on the National Ecological Network, preservation of the National Landscapes and flood risks. The study provided the province with insights that were used in the policy formulation process for the Regional Spatial Strategy. In combination with additional research, the simulation results of the spatial exploration study initiated the incorporation of specific spatial policies in the 

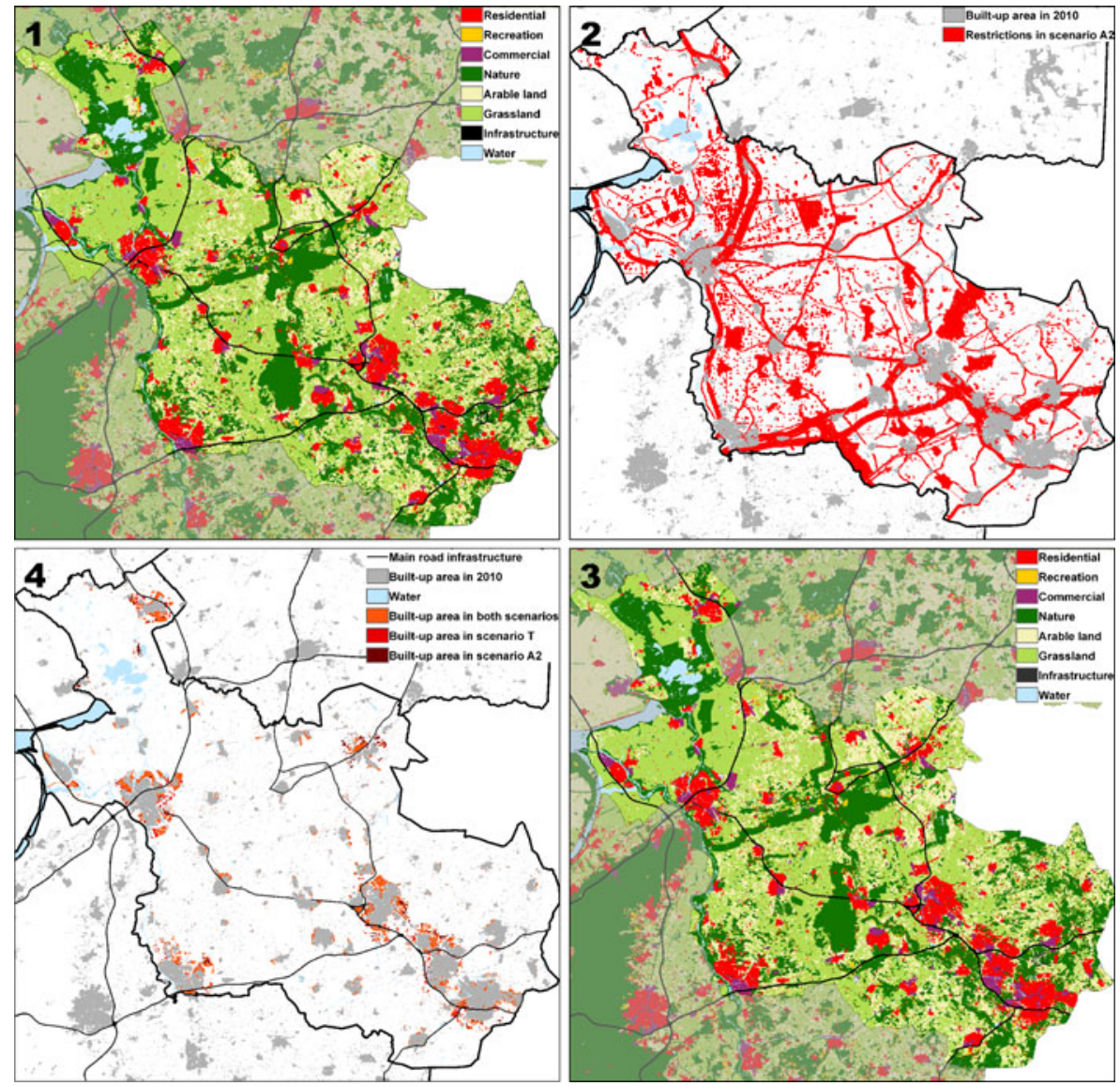

Fig. 2 The four main steps in analysing the spatial impact of the health and safety policy alternative (A2) that aims to ban residential development from areas with high levels of noise disturbance and personal safety risk, showing clockwise: 1) land use in 2040 according to the trend-based scenario; 2) restrictions to urban development; 3) land use in 2040 according to the policy alternative; and 4) differences in built-up area between the trend-based and policy alternative

legal documents related to the new Regional Spatial Strategy. This related to a more explicit delineation of the zoning regulations that aim to protect landscapes (National Landscapes) and biodiversity (National Ecological Network). Additionally, the simulation results helped delineate specific areas that specify where water storage is deemed necessary in times of excessive rainfall or flooding or where safety regulations apply that limit the development of specific types of urban land use. Special regulations were also drafted for the areas that face an increased risk of river flooding.

\section{Strategic Environmental Assessment}

The draft Regional Spatial Strategy of Overijssel was published in 2008 (Province of Overijssel 2008) and provided an integrated vision on issues, such as, spatial development, water management, mobility, soil and environment. Because the 
document set conditions for other, more detailed plans and activities related to, for example, infrastructure, rural developments and natural areas protected by European legislation (the Natura 2000 network of important ecological sites), the law required a Strategic Environmental Assessment (SEA). A draft SEA was finalised in 2008 and used in the public consultation process as annex to the draft Strategy. Based on comments from general public and other stakeholders both documents were finalised early 2009. This section focuses on the application of land-use simulation results in the drafting of the SEA (Province of Overijssel 2009).

\section{Defining Sustainability Indicators}

The province wanted to expand this SEA from a strictly environmental impact assessment towards a more encompassing sustainability impact assessment. Sustainable development was perceived here as a balanced development of human, natural and economic capital. These three aspects are often referred to as the 'people', 'planet' and 'profit' dimensions of sustainability (Elkington 1994; Hermans and Dagevos 2006). The policy impacts for these sustainability dimensions were assessed in the SEA for the proposed Regional Spatial Strategy in comparison with the current policy. "Assessing Environmental Impacts" discusses the applied indicators in more detail.

At the start of the assessment process, the Netherlands Commission for Environmental Assessment, an independent expert body that provides advisory services and capacity development on environmental assessment, suggested to do the following: develop a list of indicators to assess sustainability impacts; perform analyses to reveal current planning dilemmas and needs for policy interventions; elaborate on the role of the province; and specify impacts for Natura2000 areas (Commissie m.e.r. 2008a, b). In order to do so, a list of (qualitative and quantitative) indicators for the people, planet and profit aspects of sustainability was formulated. Whenever possible, the use of quantitative, reproducible methods was preferred over qualitative methods. Apart from assessing the sustainability impacts the SEA also meant to provide input to the policy formulation process. This included, amongst other activities, an analysis of the current planning dilemmas and needs for policy interventions. During the process, workshops were organised to present preliminary results and to introduce possible policy alternatives.

The SEA study was conducted simultaneously with the formulation of the Regional Spatial Strategy. This had the advantage that preliminary assessment results in the SEA were used by the province in the policy formulation process for the Regional Spatial Strategy and, as such, offered input for the policy formulation process. A drawback of this iterative working process was that the assessed sustainability impacts had to be updated several times to reflect the revised policies. According to the involved representatives of the province this additional work was, however, more than compensated for by the better-informed definition of the Regional Spatial Strategy (Dijk and Kuijpers-Linde 2010).

\section{Developing the Current and New Policy Alternatives}

The Land Use Scanner was applied in the SEA process to simulate future land use according to a continuation of current policy conditions (Current Policy alternative) 
and the policies outlined in the new integrated Regional Spatial Strategy (New Policy alternative). These two simulations offered the possibility to distinguish the specific spatial developments associated with the policy alternative in comparison to autonomous developments. This analysis of the additional impact of the policy alternative was the main input for the assessment of spatially explicit sustainability impacts. The assessment of the non-spatial impacts is not discussed in this paper.

Two land-use simulations were carried out: one based on the continuation of current policy (Current Policy alternative) and one based on the introduction of the Regional Spatial Strategy (New Policy alternative). The regionalised national simulations described in "Creating Regionalised Trend-based Simulations of Future Land Use" offered the starting point for these simulations. To simplify the assessment process only one scenario was applied. The moderate spatial pressure scenario was selected as the demographic and economic developments underlying this scenario were considered to be more probable than those associated with the high pressure scenario. A slightly revised version of the trend-based scenario of the regional exploration study was used as the Current Policy alternative. The new policies that were expected to replace existing ones were added to the Current Policy scenario as additional stimulations or restrictions to create the New Policy Alternative. This related to the following policy issues:

- a spatial redefinition of the National Ecological Network was incorporated that included a more detailed spatial demarcation and added a few new areas to establish a better link with water management policy;

- the current locations of greenhouses were maintained and could expand locally;

- new commercial transportation developments were stimulated on sites that are well-connected to international water, rail and road networks;

- a compact urbanisation strategy introduced in the preceding spatial exploration project was chosen in the New Policy Alternative, concentrating residential developments in the larger cities;

- recreational developments were stimulated in attractive rural areas, near the National Ecological Network or the National Landscapes.

Especially for the locations of new urban areas (highlighted in Fig. 3) the differences between the Current and New Policy alternative were considerable.

\section{Assessing Environmental Impacts}

To what degree are sustainability-related policy aims met in current and proposed policy? In most SEAs, impacts are described in a qualitative manner, using expert judgement (see, for example, VROM 2008). This makes the assessment process more difficult to reproduce, less transparent and potentially sensitive to subjectivity. In this SEA we tried to limit these problems as much as possible, striving to maximise reproducibility, transparency and objectivity in impact assessment. The Land Use Scanner played a crucial role in this respect and provided a quantitative base to support the assessment of many sustainability impacts. The degree to which the model could be used in the assessment process is indicated in Fig. 4.

In total, 28 indicators for the domains of people, planet and profit were used to assess whether the current and proposed policies managed to meet the set of selected 


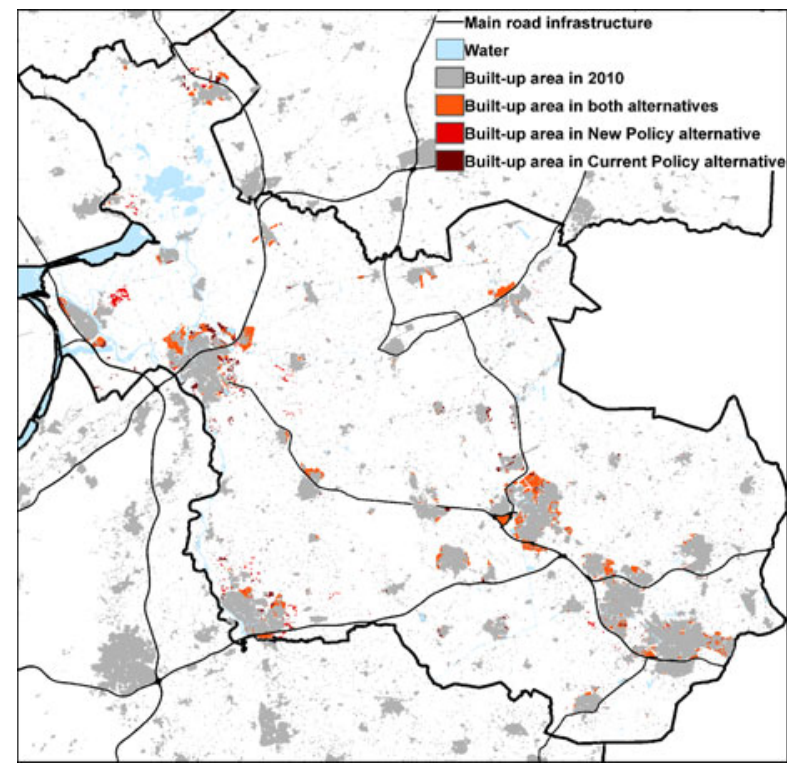

Fig. 3 Increase in built-up area in the Current and New Policy alternatives until 2040

sustainability aims. The environmental impacts were calculated using different approaches depending on the availability of established spatial data and analysis methods that could be applied within the time frame of the SEA process. Table 1 presents a selection of the 12 indicators that, to some extent, linked to policy themes for which the spatial distribution of land use is important and thus could be based on land-use information from the Land Use Scanner model. Appendix 1 describes the way these indicators were made operational and refers to additional sources of information on the included data sets and methods. The remaining 16 indicators linked to policy objectives for which land-use changes were not considered to

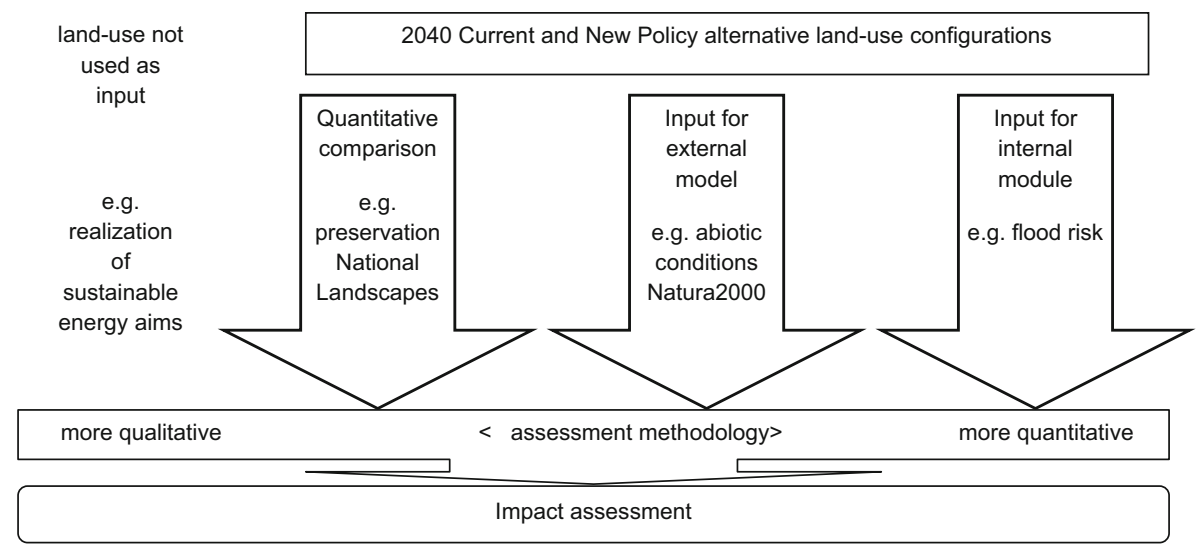

Fig. 4 Different applications of Land Use Scanner output for impact assessment in the SEA 
Table 1 Overview of the sustainability indicators related to the Land Use Scanner model

People/Landscape/Identity and diversity of landscape

People/Landscape/Landscape openness

People/Landscape/Preservation of National Landscapes

People/Safety and health/Excessive rainfall floods

People/Safety and health/River flood risk

Planet/Nature/Abiotic conditions in Natura2000 areas

Planet/Nature/Realisation National Ecological Network

Profit/Accessibility/Private motor vehicle accessibility rural areas

Profit/Accessibility/Private motor vehicle accessibility urban areas

Profit/Accessibility/Public transport accessibility rural areas

Profit/Accessibility/Public transport accessibility urban areas
Quantitative comparison

Internal assessment module

Quantitative comparison

Quantitative comparison

Internal assessment module

Input for external assessment model

Input for external assessment model Input for external assessment model

Input for external assessment model Input for external assessment model Input for external assessment model

substantially influence their achievement. This was the case with issues such as the realisation of sustainable energy aims.

Internal Land Use Scanner modules were preferably applied for impact assessment when available. As these internal modules are designed to utilise the simulation outputs no additional data-transformations were necessary. However, as Table 1 indicates, internal modules were only available for a few sustainability indicators. In case such modules lacked, the simulated land-use configurations were used as input for an external assessment model or for a quantitative comparison. To illustrate the process of indicator assessment in the SEA, an example is provided below for each of the three different types of impact assessment that were performed in relation to the land-use simulation results.

An example of an internal assessment module available within the land-use model is the analysis of river flood risk. This module was developed through the cooperative efforts of, amongst others, the Netherlands Environmental Assessment Agency (PBL), Deltares and the VU University Amsterdam and made available for application in this project through the Climate changes Spatial Planning research program (www.klimaatvoorruimte.nl). Future land-use configurations were used in this module to assess the potential economic damage and number of casualties that may result from flooding (see: Van der Hoeven et al. 2009). The results of the calculation revealed that the differences between the two policy alternatives are negligible. A more complete overview of all land-use related indicators that can be calculated within the Land Use Scanner model is available elsewhere (Bubeck and Koomen 2008).

When no internal assessment module is available, land-use patterns can be inserted in external analysis tools or models. This was, for example, the case with the analysis of coherence and abiotic conditions in the Natura2000 areas. Achieving favourable conditions in nature areas is an important policy goal. For this project a systematic approach was developed to assess the impact of various spatial developments on the basic conditions in the Natura2000 areas. Through a predefined 
set of spatial operations, made operational in an ArcGIS script, several aspects of Natura2000 areas were analysed. These related to the coherence of the existing and newly created nature areas; differences in nitrogen deposits in these areas; drought effects; and adverse built-up and other developments in the areas that have a hydrological impact on Natura2000 areas. The land-use simulations provided the potential future configurations of nature areas and new urban areas that were used as input variables in this assessment approach.

If land-use changes are deemed relevant for a sustainability issue, but internal and external assessment models are lacking, Land Use Scanner output can be used for quantitative comparison. In this SEA we analysed this by obtaining the increase in surface area of certain land-use types (in hectares) within specific zones. Such analyses were performed in a standard GIS-environment as this directly allowed the preparation of output maps for the final report, but they could easily be implemented in the land-use model. An example of such an impact assessment is provided by an indicator related to the preservation of National Landscapes. National and regional policies aim to preserve the core qualities of these landscapes by, amongst others, limiting large-scale urbanisation. To assess the degree to which this objective is met a two-step analysis was applied: first new urban areas were retrieved by comparing simulated (2040) land use with the original (2000) land use. An overlay analysis was then applied to select the new urban areas within the two National Landscapes of Overijssel. The increase in urban area within the National Landscapes was then compared between the Current and New Policy alternatives. This spatial analysis highlighted differences in the amount and location of projected urban development. The New Policy alternative contained slightly more built-up development in the National Landscapes than the Current Policy. However, this difference was considered too marginal to influence the final assessment.

The total set of 28 sustainability indicators covered a wide range of policy issues from different domains that could not readily by combined into an integrated score per policy alternative. They were, furthermore, expressed in different quantitative units (hectares, euros, casualties, traffic flows, see Appendix 1) or even qualitative in nature and thus lacked a unifying principle that could be used to easily standardise their scores as is common in methods such as the goals-achievement matrix (GAM, see Pettit and Pullar 2004) or related multi-criteria analysis. Advanced standardisation of the scores as is, for example, advocated in recent work building on Life Cycle Assessment (LCA) Impact Analysis thresholds (Walter and Stützel 2009) was not considered appropriate in this case. Our main concern was that we did not want to suggest decision makers and other stakeholders that impacts on, for example, personal safety can be represented, let alone compared, on the same scale as economic development potential or landscape preservation. The evaluation of the importance of these impacts was considered to be part of the political decision making process and not of the science-based analysis of impacts. Instead, the indicator scores were only used in a relative sense; they were used to compare the future state according to a policy alternative with the present situation and to compare between the two policy alternatives. In the report's summary these comparisons were visualised per indicator with a simple colouring scheme: green when the future state was considered to be an improvement compared to the current situation, red for a deterioration and yellow when no change occurs. In addition, the 
score of the New Policy alternative relative to Current Policy alternative was summarised in simple symbols ( $\boldsymbol{\Delta}$ representing an improvement etc.).

\section{Discussion and Conclusion}

The Land Use Scanner proved to be a useful tool for regional planning support in the Dutch province of Overijssel. Different capacities of the model were used in the subsequent definition and evaluation phase of establishing a Regional Spatial Strategy. An initial spatial exploration study focussed on the representation of potential spatial developments according to two trend-based scenarios and the optimisation of land-use patterns according to three, rather hypothetical, sets of policy objectives. The subsequent SEA relied on the model's ability to provide probable land-use patterns related to an integrated policy alternative that could be used as input in various impact assessments. This section briefly discusses the merits of the applied modelling approach; first touching upon the spatial exploration study and then dwelling on the SEA. It finishes with several comments on the general applicability of spatially explicit land-use models in the context of strategic regional planning.

\section{Exploring Spatial Policy Objectives}

In the initial spatial exploration study the Land Use Scanner was used to frame current policy objectives and simulate land-use patterns according to three coherent sets of policy objectives related to: 1) water management; 2) safety and health; and 3) compact urbanisation. In cooperation with the province the quality of the initial input data of the model was improved by replacing several national data sets with more recent and more accurate regional policy-related data sets. In combination with regional knowledge on ongoing spatial developments and anticipated changes (e.g. the demand for specific types of housing), this allowed the creation of regionalised future land-use configurations according to two trendbased scenarios. These offered a solid framework to develop and compare the three different policy alternatives. As the same economic, demographic and other scenario assumptions - and thus the same quantities of land-use change-were used in these simulations, they offered a clear view on the specific implications of the spatial policy alternatives. The comparison, therefore, revealed potential (unwanted) spatial impacts directly related to the three proposed sets of spatially explicit policies.

The use of two trend-based reference scenarios allowed the assessment of these impacts under different levels of spatial pressure. The inclusion of more diverse reference scenarios would have provided an even more robust assessment of the impacts of the policy alternatives. But this benefit would have come at the cost of obscuring the specific impacts associated with these alternatives as more variation in the spatial developments would be introduced.

An initially underestimated but significant benefit of the modelling process lay in its iterative, open character and its ability to transfer preliminary planning concepts into spatially explicit potential outcomes. The presentation of intermediate 
results (land use and related impact maps) in workshop-type sessions allowed provincial policy makers with different professional expertise (water, nature, residential etc.) to discuss potential developments, propose alternative policies and, above all, clarify their suggested planning interventions in a shared spatial environment. Based on these discussions the modellers could incorporate new spatial data sets and adjust model settings (e.g. related to suitable locations for specific land-use types) to better simulate land use according to the proposed policy interventions. In the interactive group process of constructing a coherent Regional Spatial Strategy the spatially explicit modelling approach provided a means to explore and integrate sector-specific interests and thus aid the policy formulation process. The discussions on intermediate land-use simulation results were a much-valued opportunity for the different policy makers to get a clearer understanding of each other's proposals and potential feedbacks between different policy themes.

\section{Linking Land-use Modelling and SEA}

The subsequent SEA of the Regional Spatial Strategy is unique as it is the first Dutch SEA in which land-use modelling results were used in the sustainability assessment process. SEAs are often fairly qualitative and non-transparent in the description of the proposed policies and related impacts. The use of the Land Use Scanner helped making this planning process more transparent and reproducible in two ways.

Firstly, it forced the proposed polices to be specified in a more concrete and unambiguous way, as they could otherwise not be included in the model. This increased concreteness facilitated the discussion among the involved policymakers about to be implemented policies during the policy formulation process. The sharpened description and depiction as land-use maps of the proposed policies in the published Regional Spatial Strategy (Province of Overijssel 2008), furthermore, provided additional clarity to other stakeholders and the general public.

Secondly, part of the impact assessment was done in a more analytic way, providing relatively clear results in the form of quantitative impact assessments and spatially explicit impact maps. This quantitative part of the assessment process is more transparent then the hitherto more common qualitative description of impacts as it makes use of reproducible methods that are documented in the full SEA report and other sources that are available to stakeholders and the general public.

These two advantages were partially acknowledged by the Netherlands Commission for Environmental Assessment that issues non-binding advice to government agencies responsible for environmental assessments. This independent expert body welcomed the attempts to clarify the policy intentions and the newly developed impact assessment framework, but suggested that the impact assessments methods should be developed further and described in more detail and, furthermore, criticised the lack of a clear implementation strategy of the suggested policies (Commissie m.e.r. 2009). The former suggestion was addressed by providing additional documentation on the applied assessment methods as the further development of additional assessment tools was not feasible within the time frame 
of the project. The latter comment indicates a more general issue in establishing strategic spatial policies; in our experience these often fail to become concrete and spatially explicit. To some extent this is inherent to the very nature of strategic visions; these documents outline development directions rather than development plans that belong more to the local level. But the difficulty of becoming concrete may also have more fundamental reasons such as the lack of a common understanding about what constitutes 'spatial planning', and what conceptions of space and place underpin it (Davoudi and Strange 2009) or the increasing spatial complexities at regional or metropolitan level (de Jong and Spaans 2009; Salet and Woltjer 2009).

Based on our experiences we believe that the SEA process in combination with a spatially explicit land-use model and quantitative impact assessments tools can help drafting more concrete strategic visions, although this may call for the provision of additional resources and an adjustment in the current - more qualitatively orientedway of working. The involved provincial policy makers greatly appreciated the results of this particular SEA and its land-use modelling based assessment process as these clarified discussions on potential spatial developments and related sustainability impacts (Dijk and Kuijpers-Linde 2010). Conversely, the active involvement of policy makers from a range of different disciplinary backgrounds in the definition of policy alternatives and evaluation of initial impact assessments contributed to the successful application of the land-use modelling framework. This underlines the need for planning support systems to facilitate an integrated, interdisciplinary approach and involve stakeholders in their application as is advocated by Carsjens (2009). Several discussion sessions were, however, necessary to fully explain the assessment process and especially the land-use allocation approach. This indicates the need for a clear explanation of all individual steps in the process and the use straightforward, well-documented assessment methods.

\section{General Land-use Modelling Issues}

The studies also revealed several more general modelling issues that we also encountered in similar studies performed for other provinces that used the same land-use modelling approach (Atzema et al. 2008; Kuijpers-Linde et al. 2008). These issues related to the treatment of uncertainty, the trust planners have in the success of planning initiatives and the need for integrated data infrastructures. Each of these issues is briefly explained below.

In our experience planners, in general, do not like uncertainty. This has been observed by others before (e.g. Christensen 1985; Dantzig 1999) and also shows from the presented simulations of land-use change. In this case, as well as in comparable studies performed for other provinces, policy makers preferred to use only one trend-based reference scenario as they considered the inclusion of more reference points confusing. This means that uncertainty is only marginally addressed in the land-use simulations. Implicitly, strong confidence is expressed in the validity of the assumed trend-based conditions that underlie them. However, this approach has several weaknesses. Extrapolation of current trends and policies is not necessarily likely to produce plausible results as past changes are no guarantee for future changes. Using only one trend obscures the fact that any projection of future socio-economic conditions has a high degree of uncertainty. In fact, the so-called 
trends are to some extent based on scenario-assumptions as is the case with moderate and high growth projections that were used to specify the demand for residential land in the presented study. To combine these scenario-based assumptions with other trends that do not follow the same scenario conditions is inconsistent. These issues are not particularly worrisome when simulations are only used to visualise planning concepts. But when land-use simulations have a more substantial role in the formulation process (for example to highlight potential controversial spatial developments or the impact of policies in Strategic Environmental Assessments) the definition of more solid reference points becomes essential. For long-term projections (e.g. 30 years or more) we, therefore, advocate the use of a small set of, for example, two to four scenarios covering most of the uncertainty related to key socio-economic conditions to address a larger bandwidth of potential developments. To meet the policymakers' need to limit uncertainty in studies related to concrete planning initiatives for the short term (e.g. 15-20 years) it would be good to create a well-founded and validated reference scenario that incorporates current trends and policies. Explicit attention should be paid here to underpinning the expected degree of success of the included policies as is discussed hereafter. To visualise the inherent uncertainty in the land-use maps and associated representations of potential impacts resulting from scenarios-based studies, use can be made of fuzzified representations (Vullings et al. 2007, 2009). In a land-use modelling context this can be done by applying moving-window type of filtering techniques to enhance concentrations of specific types of land use or impact values. This potentially effective approach to deal with uncertainty was not applied in the current study due to time constraints. On a more fundamental level, stochastic modelling techniques can be applied to address uncertainty (Dantzig 1999); for example in describing the strength of specific driving forces that steer land use change. Knowing the planners' uncertainty aversion, however, we refrained from applying such an approach.

Prominent in the presented land-use simulations was the assumption that the proposed spatial policies will actually be applied and that they will become fully effective. The model thus showed what may happen if a certain policy is successfully put in place. In practice, spatial restrictions or stimulation policies are often not as effective as intended. Even the spatial policies that can be considered relatively successful, such as the national Buffer Zones in the Netherlands intended to keep green spaces between the major cities free from urban development, do not fully stop urbanisation (Koomen et al. 2008d). The actual degree of success of planning initiatives is especially relevant when the aim of the study is to assess the impact of a specific policy. The model has the flexibility to account for partial effectiveness of the implemented policies, but quantitative assessments of the degree of success of different types of spatial policies are often lacking in planning literature. This indicates a more generally felt lack of ex-post evaluations of spatial plans and concepts (Lee 2006; Marshall et al. 2005; OECD 2010). The dynamic, interrelated and often vague nature of most spatial plans and policies makes this a difficult issue of course, and establishing the effectiveness of new planning concepts that have no historic parallel is obviously close to impossible. Yet, more attempts in this direction would greatly enhance planning in general and our type of land-use modelling in particular. 
Furthermore, consistent, up-to-date and detailed input data are a prerequisite for successful modelling. In this study the required data were scattered across three different departments of the province and stored in a range of different data formats. Different departments even used different socio-economic scenarios for various sector-specific outlooks on the future. In comparable studies performed for other provinces we encountered similar experiences. The emphasis various (supra)national authorities currently put on spatial data-infrastructures and related geo-portals will hopefully improve data consistency and availability and enhance the potential for spatial analysis in general and land-use modelling in particular (EC 2007; Maguire and Longley 2005; Vanderhaegen and Muro 2005).

\section{Suggestions for Further Research}

In conclusion, we advocate the development of integrated spatial impact assessment platforms based on land-use modelling frameworks to assist planners in the analysis of potential spatial developments, the exploration and definition of policy alternatives and the assessment of their potential impacts. Based on our experiences we suggest researchers in this field to focus on:

- the definition of well-established and generally accepted trend-based reference scenarios of future land use-change in the short term (15-20 years);

- performing ex-post evaluations of the actual success of planning initiatives in order to attach a degree of confidence to new planning initiatives that are the topic of ex-ante evaluations;

- the application of fuzzified representation techniques to land-use and related impacts maps ensuring that uncertainty is addressed in a way that is understandable to planners;

- developing more elaborate impact assessment modules within or closely linked to a land-use model and relating to themes such as accessibility, safety and health (e.g. air pollution and external safety) to create a more extensive, quantitative assessment base;

- the provision of spatial data infrastructures with related geo-portals to improve data consistency and availability for spatial analysis.

With sufficient research progress in these five themes we are confident that the assessment of spatial impacts based on land-use modelling frameworks will become more widespread in strategic regional planning in the near future.

Acknowledgements The authors are grateful to the Netherlands Environmental Assessment Agency (PBL) that provided the Land Use Scanner model and initial application for this research. Special thanks are expressed to Willem Loonen for performing the land-use simulations described in the paper and Marianne Kuijpers-Linde for developing the sustainability framework applied here. We, furthermore, thank the Dutch National research program Climate changes spatial planning for financing part of the presented research. Last, but not least, we are thankful to the two anonymous reviewers for their constructive comments that helped improve this paper.

Open Access This article is distributed under the terms of the Creative Commons Attribution Noncommercial License which permits any noncommercial use, distribution, and reproduction in any medium, provided the original author(s) and source are credited. 


\section{Appendix 1}

Table 2 Characteristics of the land-use based indicators

\begin{tabular}{|c|c|c|c|}
\hline $\begin{array}{l}\text { Sustainability theme/ } \\
\text { Aspect/Indicator }\end{array}$ & Operationalisation of indicator & $\begin{array}{l}\text { Reference to data or method } \\
\text { description }\end{array}$ & $\begin{array}{l}\text { Relation to Land Use } \\
\text { Scanner model }\end{array}$ \\
\hline $\begin{array}{l}\text { People/Landscape/ } \\
\text { Identity and diversity } \\
\text { of landscape }\end{array}$ & $\begin{array}{l}\text { Indication of the urban pressure } \\
\text { (total amount of new built-up } \\
\text { area in ha) on highly valued } \\
\text { landscapes used as part of } \\
\text { more qualitative landscape } \\
\text { impact assessment. }\end{array}$ & $\begin{array}{l}\text { Highly valued landscapes } \\
\text { dataset provided by Roos- } \\
\text { Klein Lankhorst et al. } \\
\text { (2005) based on national } \\
\text { survey }\end{array}$ & $\begin{array}{l}\text { Quantitative comparison } \\
\text { (GIS-based overlay) }\end{array}$ \\
\hline $\begin{array}{l}\text { People/Landscape/ } \\
\text { Landscape openness }\end{array}$ & $\begin{array}{l}\text { Loss of open area (in ha) in the } \\
\text { province. Open area is defined } \\
\text { as a contiguous open (not } \\
\text { built-up) area with a minimum } \\
\text { size of } 2.5 \mathrm{~km}^{2} \text { without major } \\
\text { infrastructure or building } \\
\text { concentrations. }\end{array}$ & $\begin{array}{l}\text { Bubeck \& Koomen (2008) } \\
\text { describe the applied } \\
\text { method in more detail }\end{array}$ & $\begin{array}{l}\text { Internal assessment } \\
\text { module }\end{array}$ \\
\hline $\begin{array}{l}\text { People/Landscapes/ } \\
\text { Preservation of } \\
\text { National Landscapes }\end{array}$ & $\begin{array}{l}\text { Calculation of the amount of } \\
\text { new built-up area (residential, } \\
\text { commercial, infrastructure or } \\
\text { greenhouses) in hectares } \\
\text { within the two National } \\
\text { Landscapes designated in } \\
\text { the province. }\end{array}$ & $\begin{array}{l}\text { Designated National Landscape } \\
\text { provided by Province of } \\
\text { Overijssel (2008) }\end{array}$ & $\begin{array}{l}\text { Quantitative comparison } \\
\text { (GIS-based overlay) }\end{array}$ \\
\hline $\begin{array}{l}\text { People/Safety and } \\
\text { health/Excessive } \\
\text { rainfall floods }\end{array}$ & $\begin{array}{l}\text { Assessment of the increase in } \\
\text { built-up area (in ha) in areas } \\
\text { that are likely to be affected } \\
\text { by excessive rainfall. }\end{array}$ & $\begin{array}{l}\text { Dataset describing potential } \\
\text { rain-induced flood areas } \\
\text { based on hydrological } \\
\text { modelling provided by } \\
\text { Province of Overijssel }\end{array}$ & $\begin{array}{l}\text { Quantitative comparison } \\
\text { (GIS-based overlay) }\end{array}$ \\
\hline $\begin{array}{l}\text { People/Safety and } \\
\text { health/River flood } \\
\text { risk }\end{array}$ & $\begin{array}{l}\text { Calculation of the potential } \\
\text { damage (in euros) and number } \\
\text { of casualties in river-flood } \\
\text { prone areas based on spatial } \\
\text { distribution of various } \\
\text { land-use types. }\end{array}$ & $\begin{array}{l}\text { Van der Hoeven et al. (2009) } \\
\text { describe the applied method } \\
\text { that combines hydrologic } \\
\text { modelling results with } \\
\text { socio-economic assessment } \\
\text { rules. }\end{array}$ & $\begin{array}{l}\text { Internal assessment } \\
\text { module }\end{array}$ \\
\hline $\begin{array}{l}\text { Planet/Nature/Abiotic } \\
\text { conditions in } \\
\text { Natura2000 areas }\end{array}$ & $\begin{array}{l}\text { As part of the evaluation of } \\
\text { the abiotic conditions within } \\
\text { the } 25 \text { Natura } 2000 \text { areas in } \\
\text { Overijssel the impact of } \\
\text { the simulated increase in } \\
\text { built-up area and spatial } \\
\text { configuration of nature } \\
\text { areas was assessed with } \\
\text { a GIS-based method. }\end{array}$ & $\begin{array}{l}\text { Province of Overijssel (2009) } \\
\text { describes the applied } \\
\text { method }\end{array}$ & $\begin{array}{l}\text { Input for external } \\
\text { assessment model }\end{array}$ \\
\hline $\begin{array}{l}\text { Planet/Nature/ } \\
\text { Realisation } \\
\text { National Ecological } \\
\text { Network }\end{array}$ & $\begin{array}{l}\text { Analysis of the biodiversity } \\
\text { impact of the simulated } \\
\text { spatial distribution of nature } \\
\text { area performed with an } \\
\text { external expert model. }\end{array}$ & $\begin{array}{l}\text { Van Eupen (2008) describes } \\
\text { the applied method in detail }\end{array}$ & $\begin{array}{l}\text { Input for external } \\
\text { assessment model }\end{array}$ \\
\hline $\begin{array}{l}\text { Profit/Accessibility/ } \\
\text { Private motor vehicle } \\
\text { accessibility rural } \\
\text { areas }\end{array}$ & $\begin{array}{l}\text { The amount of additional traffic } \\
\text { generated by new urban } \\
\text { development was taken into } \\
\text { account in the regional } \\
\text { transportation model NRM } \\
\text { that simulates future } \\
\text { transport flows for different } \\
\text { travel modes }\end{array}$ & $\begin{array}{l}\text { Transport model is described } \\
\text { by AVV (2006) }\end{array}$ & $\begin{array}{l}\text { Input for external } \\
\text { assessment model }\end{array}$ \\
\hline
\end{tabular}


Table 2 (continued)

\begin{tabular}{|c|c|c|c|}
\hline $\begin{array}{l}\text { Sustainability theme/ } \\
\text { Aspect/Indicator }\end{array}$ & Operationalisation of indicator & $\begin{array}{l}\text { Reference to data or method } \\
\text { description }\end{array}$ & $\begin{array}{l}\text { Relation to Land Use } \\
\text { Scanner model }\end{array}$ \\
\hline $\begin{array}{l}\text { Profit/Accessibility/ } \\
\text { Private motor vehicle } \\
\text { accessibility urban } \\
\text { areas }\end{array}$ & $\begin{array}{l}\text { The amount of additional traffic } \\
\text { generated by new urban } \\
\text { development was taken into } \\
\text { account in a regional } \\
\text { transportation model (NRM) } \\
\text { that simulates future } \\
\text { transport flows for } \\
\text { different travel modes }\end{array}$ & $\begin{array}{l}\text { Transport model is described } \\
\text { by AVV (2006) }\end{array}$ & $\begin{array}{l}\text { Input for external } \\
\text { assessment model }\end{array}$ \\
\hline $\begin{array}{l}\text { Profit/Accessibility/ } \\
\text { Public transport } \\
\text { accessibility rural } \\
\text { areas }\end{array}$ & $\begin{array}{l}\text { The amount of additional traffic } \\
\text { generated by new urban } \\
\text { development was taken into } \\
\text { account in the regional } \\
\text { transportation model NRM } \\
\text { that simulates future } \\
\text { transport flows for } \\
\text { different travel modes }\end{array}$ & $\begin{array}{l}\text { Transport model is described } \\
\text { by AVV (2006) }\end{array}$ & $\begin{array}{l}\text { Input for external } \\
\text { assessment model }\end{array}$ \\
\hline $\begin{array}{l}\text { Profit/Accessibility/ } \\
\text { Public transport } \\
\text { accessibility urban } \\
\text { areas }\end{array}$ & $\begin{array}{l}\text { The amount of additional traffic } \\
\text { generated by new urban } \\
\text { development was taken into } \\
\text { account in the regional } \\
\text { transportation model NRM } \\
\text { that simulates future } \\
\text { accessibility for different } \\
\text { travel modes }\end{array}$ & $\begin{array}{l}\text { Transport model is described } \\
\text { by AVV (2006) }\end{array}$ & $\begin{array}{l}\text { Input for external } \\
\text { assessment model }\end{array}$ \\
\hline $\begin{array}{l}\text { Profit/Economy/Zero- } \\
\text { grazing livestock } \\
\text { farm development } \\
\text { potential }\end{array}$ & $\begin{array}{l}\text { Availability of sufficient } \\
\text { locations for zero-grazing } \\
\text { livestock farms to relocate } \\
\text { or expand assessed with } \\
\text { Land Use Scanner as part } \\
\text { of the allocation process } \\
\text { that balances supply with } \\
\text { demand for land. }\end{array}$ & $\begin{array}{l}\text { Spatial datasets with restrictions } \\
\text { and development locations for } \\
\text { zero-grazing livestock were } \\
\text { provided by Province of } \\
\text { Overijssel (2009). }\end{array}$ & $\begin{array}{l}\text { Internal assessment } \\
\text { module }\end{array}$ \\
\hline
\end{tabular}

\section{References}

Agarwal, C., Green, G. M., Grove, J. M., Evans, T. P., \& Schweik, C. M. (2002). A review and assessment of land-use change models: Dynamics of space, time, and human choice. Gen. Tech. Rep. NE-297. U.S. Department of Agriculture, Forest Service, Northeastern Research Station, Newton Square, PA. Arcadis and Stec Groep. (2007). Integraal Bedrijventerreinen Informatie Systeem, De stand in planning en uitgifte van bedrijventerreinen 1 januari 2007 en de uitgifte in 2006. Amersfoort: Arcadis/Stec Groep. Atzema, O., Van Egmond, K., Mommaas, H., Wenting, R., \& Kuijpers-Linde, M. (2008). Utrecht 2040; Strategische notities in het kader van het traject 'Samen op Weg naar 2040' van de Provincie Utrecht. Utrecht: Universiteit Utrecht Faculteit Geowetenschappen.

AVV. (2006). NRM handboek versie 3.0. Rotterdam: Adviesdienst Verkeer en Vervoer.

Borsboom-van Beurden, J., \& Koomen, E. (2010). The LUMOS approach; land-use modelling in the Dutch planning practice. Netherlands Environmental Assessment Agency, Bilthoven (forthcoming).

Borsboom-van Beurden, J. A. M., Bakema, A., \& Tijbosch, H. (2007). A land-use modelling system for environmental impact assessment; Recent applications of the LUMOS toolbox. Chapter 16. In E. Koomen, J. Stillwell, A. Bakema, \& H. J. Scholten (Eds.), Modelling land-use change; progress and applications (pp. 281-296). Dordrecht: Springer.

Bubeck, P., \& Koomen, E. (2008). The use of quantitative evaluation measures in land-use change projections; An inventory of indicators available in the Land Use Scanner. Spinlab Research Memorandum SL-07. Amsterdam: Vrije Universiteit Amsterdam/SPINlab. 
Carsjens, G. J. (2009). Supporting strategic spatial planning. PhD thesis. Wageningen University, Wageningen. Christensen, K. S. (1985). Coping with uncertainty in planning. Journal of the American Planning Organisation, 51(1), 63-73.

Commissie m.e.r. (2008a). Aanvullend advies over de reikwijdte en het detailniveau van het milieueffectrapport, rapportnummer 2066-76. Utrecht: Commissie Voor de Milieueffectrapportage.

Commissie m.e.r. (2008b). Advies over de reikwijdte en het detailniveau van het milieueffectrapport, rapportnummer 2066-40. Utrecht: Commissie Voor de Milieueffectrapportage.

Commissie m.e.r. (2009). Omgevingsvisie Overijssel; Toetsingsadvies over het milieueffectrapport, rapportnummer 2066-157. Utrecht: Commissie Voor de Milieueffectrapportage.

CPB, MNP, \& RPB. (2006). Welvaart en Leefomgeving. Een scenariostudie voor Nederland in 2040. Den Haag: Centraal Planbureau, Milieu-en Natuurplanbureau en Ruimtelijk Planbureau.

Dantzig, G. B. (1999). Planning under uncertainty. Annals of Operations Research, 85(0).

Davoudi, S., \& Strange, I. (2009). Conceptions of space and place in strategic spatial planning. London: Routledge.

de Jong, K. (2009). The Dutch National Ecological Network and National Landscapes, Reinforcing or contradicting policy on a square metre? Student thesis. University of Groningen/ IVEM, Groningen.

de Jong, J., \& Spaans, M. (2009). Trade-offs at a regional level in spatial planning: two case studies as a source of inspiration. Land Use Policy, 26(2), 368-379.

Dekkers, J. E. C., \& Koomen, E. (2006). De rol van sectorale inputmodellen in ruimtegebruiksimulatie; Onderzoek naar de modellenketen voor de LUMOS toolbox. SPINlab research memorandum SL-05. Amsterdam: Vrije Universiteit Amsterdam.

Dekkers, J. E. C., \& Koomen, E. (2007). Land-use simulation for water management: application of the Land Use Scanner model in two large-scale scenario-studies. Chapter 20. In E. Koomen, J. Stillwell, A. Bakema, \& H. J. Scholten (Eds.), Modelling land-use change; progress and applications (pp. 355373). Dordrecht: Springer.

Dijk, E., \& Kuijpers-Linde, M. (2010). Een planMER met duurzaamheidsbeoordeling voor provinciale Omgevingsvisie: Belangrijke schakel in de kennisketen. Toets (forthcoming).

EC (2007). Directive 2007/2/EC of the European Parliament and of the Council of 14 March 2007 establishing an Infrastructure for Spatial Information in the European Community (INSPIRE). Official Journal of the European Union: L 50(108).

Elkington, J. (1994). Towards the sustainable corporation: win-win-win business strategies for sustainable development. California Management Review, 36(2), 90-100.

Geertman, S., \& Stillwell, J. (2009). Planning Support Systems: Content, issues and trends. Chapter 1. In: Planning support systems best practice and new methods. Springer, Netherlands, pp. 1-26.

Geoghegan, J., Schneider, L., \& Vance, C. (2004). Temporal dynamics and spatial scales: modeling deforestation in the southern Yucatán peninsular region. Geojournal, 61(4), 353-363.

Hermans, F., \& Dagevos, J. (2006). De duurzaamheidsbalans van Brabant 2006. Tilburg: Telos.

Hilferink, M., \& Rietveld, P. (1999). Land use scanner: an integrated GIS based model for long term projections of land use in urban and rural areas. Journal of Geographical Systems, 1(2), 155-177.

Hoymann, J. (2010). Accelerating urban sprawl in depopulating regions: a scenario analysis for the Elbe River Basin. Regional Environmental Change. doi:10.1007/s10113-010-0120-x.

Jongman, R. H. G., Knlvik, M., \& Kristiansen, I. (2004). European ecological networks and greenways. Landscape and Urban Planning, 68(2-3), 305-319.

Kabat, P., van Vierssen, W., Veraart, J., Vellinga, P., \& Aerts, J. (2005). Climate proofing the Netherlands. Nature, 438(7066), 283-284.

Klosterman, R. E. (1999). The what if? Collaborative planning support system. Environment and Planning B: Planning and Design, 26, 393-408.

Koomen, E., \& Stillwell, J. (2007). Modelling land-use change; Theories and methods. Chapter 1. In E. Koomen, J. Stillwell, A. Bakema, \& H. J. Scholten (Eds.), Modelling land-use change; progress and applications (pp. 1-21). Dordrecht: Springer.

Koomen, E., Kuhlman, T., Groen, J., \& Bouwman, A. A. (2005). Simulating the future of agricultural land use in the Netherlands. Tijdschrift voor Economische en Sociale Geografie (Journal of Economic and Social Geography), 96(2), 218-224.

Koomen, E., Stillwell, J., Bakema, A., \& Scholten, H. J. (2007). Modelling land-use change; progress and applications. Geojournal library, volume 90. Dordrecht: Springer.

Koomen, E., Kuijpers-Linde, M., \& Loonen, W. (2008). Ruimtelijke verkenning Overijssel 2040. Amsterdam: Geodan Next.

Koomen, E., Loonen, W., \& Hilferink, M. (2008). Climate-change adaptations in land-use planning; a scenario-based approach. In L. Bernard, A. Friis-Christensen, \& H. Pundt (Eds.), The European 
Information Society; Taking Geoinformation Science One Step Further (pp. 261-282). Berlin: Springer.

Koomen, E., Rietveld, P., \& De Nijs, T. (2008). Modelling land-use change for spatial planning support; Editorial. Annals of Regional Science, 42(1), 1-10.

Koomen, E., Dekkers, J., \& Van Dijk, T. (2008). Open space preservation in the Netherlands: planning, practice and prospects. Land Use Policy, 25(3), 361-377.

Kuijpers-Linde, M., Koekoek, A., \& Loonen, W. (2008). Uitwerking ruimtelijke beelden voor het nieuwe omgevingsbeleid van Drenthe. Werknotitie. Amsterdam: Geodan Next.

Landis, J. D. (1994). The California urban futures model: a new generation of metropolitan simulation models. Environment and Planning B: Planning and Design, 21, 399-420.

Lee, N. (2006). Bridging the gap between theory and practice in integrated assessment. Environmental Impact Assessment Review, 26(1), 57-78.

Loonen, W., \& Koomen, E. (2009). Calibration and validation of the Land Use Scanner allocation algorithms. PBL-report. Bilthoven: Netherlands Environmental Assessment Agency.

Loonen, W., Heuberger, P., \& Kuijpers-Linde, M. (2007). Spatial optimisation in land-use allocation problems. Chapter 9. In E. Koomen, J. Stillwell, A. Bakema, \& H. J. Scholten (Eds.), Modelling landuse change; progress and applications (pp. 147-165). Dordrecht: Springer.

Maguire, D. J., \& Longley, P. A. (2005). The emergence of geoportals and their role in spatial data infrastructures. Computers, Environment and Urban Systems, 29(1), 3-14.

Marshall, R., Arts, J., \& Morrison-Sanders, A. (2005). Principles for EIA follow-up; International principles for best practice EIA follow-up. Impact Assessment and Project Appraisal, 23(3), 175181.

Mudgal, S., Benoit, P., \& Koomen, E. (2008). Modelling of EU land-use choices and environmental impacts; Scoping study-Final report. Brussels: EC-DG Environment/BIO Intelligence Service.

OECD. (2010). Proceedings from the OECD expert meeting on regulatory performance: Ex post evaluation of regulatory policies. Paris: OECD.

Parker, D. C., Manson, S. M., Janssen, M., Hoffmann, M. J., \& Deadman, P. J. (2003). Multi-agent systems for the simulation of land use and land cover change: a review. Annals of the Association of American Geographers, 93(2), 316-340.

PBL. (2010). The Netherlands in the future. Second sustainability outlook: The physical living environment in the Netherlands. Bilthoven: Netherlands Environmental Assessment Agency (PBL).

Pettit, C., \& Pullar, D. (2004). A way forward for land-use planning to achieve policy goals by using spatial modelling scenarios. Environment and Planning B: Planning and Design, 31, $213-233$.

Pontius, R. G., Jr., Boersma, W., Castella, J.-C., Clarke, K., De Nijs, T., Dietzel, C., et al. (2008). Comparing the input, output, and validation maps for several models of land change. Annals of Regional Science, 42(1), 11-37.

Province of Overijssel. (2008). Ontwerp Omgevingsvisie; visie en uitvoeringsprogramma voor de ontwikkeling van de fysieke leefomgeving in de Provincie Overijssel. Zwolle: Provincie Overijssel.

Province of Overijssel. (2009). PlanMER Omgevingsvisie. Zwolle: Provincie Overijssel.

Roos-Klein Lankhorst, J., De Vries, S., Buijs, A. E., Bloemmen, M. H. I., \& Schuiling, C. (2005). BelevingsGIS versie 2; Waardering van het Nederlandse landschap door de bevolking op kaart. Rapport 1138. Wageningen: Alterra, Research Instituut voor de Groene Ruimte.

Salet, W., \& Woltjer, J. (2009). New concepts of strategic spatial planning dilemmas in the Dutch Randstad region. International Journal of Public Sector Management, 22(3), 235-248.

Scholten, H. J., Van de Velde, R. J., Rietveld, P., \& Hilferink, M. (1999). Spatial information infrastructure for scenario planning: the development of a Land Use Planner for Holland. In J. Stillwell, S. Geertman, \& S. Openshaw (Eds.), Geographical information and planning (pp. 112-134). Berlin: Springer.

Schotten, C. G. J., Heunks, C., Wagtendonk, A. J., Buurman, J. J. G., de Zeeuw, C. J., Kramer, H., et al. (2001). Simulating Europe in the 21th century. NRSP-2 report 00-22. Delft: BCRS.

Schotten, C. G. J., Goetgeluk, R. W., Hilferink, M., Rietveld, P., \& Scholten, H. J. (2001b). Residential construction, land use and the environment. Simulations for The Netherlands using a GIS-based land use model. Environmental Modelling and Asessment 6.

Sheridan, P., Schroers, J. O., \& Rommelfanger, E. (2007). GIS-based modelling of land-use systems; EU Common Agricultural Policy reform and its impact on agricultural land use and plant species richness. Chapter 21. In E. Koomen, J. Stillwell, A. Bakema, \& H. J. Scholten (Eds.), Modelling land-use change; progress and applications (pp. 375-389). Dordrecht: Springer.

Stillwell, J. C. H., Geertman, S., \& Openshaw, S. (1999). Geographical information and planning. Advances in spatial science. Berlin: Springer. 
Van der Hoeven, E., Aerts, J., Van der Klis, H., \& Koomen, E. (2009). An Integrated Discussion Support System for new Dutch flood risk management strategies. In S. Geertman \& J. C. H. Stillwell (Eds.), Planning support systems: Best practices and new methods. Berlin: Springer.

Van Eupen, M. (2008). Concept herbegrenzing PEHS. Concept. Alterra: Wageningen.

Van Leeuwen, E., Koetse, M., Koomen, E., \& Rietveld, P. (2009). Spatial economic research on climate change and adaptation; Literature review for 'Knowledge for Climate'. KfC report number KfC 002/09. Amsterdam: Vrije Universiteit.

Van Meijl, H., Van Rheenen, T., Tabeau, A., \& Eickhout, B. (2006). The impact of different policy environments on agricultural land use in Europe. Agriculture, Ecosystems \& Environment, 114(1), 21-38.

Vanderhaegen, M., \& Muro, E. (2005). Contribution of a European spatial data infrastructure to the effectiveness of EIA and SEA studies. Environmental Impact Assessment Review, 25(2), 123-142.

Vedung, E. (1997). Public policy and program evaluation. New Brunswck: Transaction Publishers.

Veldkamp, A., \& Verburg, P. H. (2004). Modelling land use change and environmental impact. Journal of Environmental Management, 72(1-2), 1-3.

Verburg, P. H., \& Overmars, K. P. (2007). Dynamic simulation of land-use trajectories with the CLUE-s model. Chapter 18. In E. Koomen, J. Stillwell, A. Bakema, \& H. J. Scholten (Eds.), Modelling landuse change; progress and applications (pp. 321-335). Dordrecht: Springer.

Verburg, P. H., Schot, P. P., Dijst, M. J., \& Veldkamp, A. (2004). Land use change modelling: current practice and research priorities. Geojournal, 61, 309-324.

Verburg, P. H., Rounsevell, M. D. A., \& Veldkamp, A. (2006). Scenario-based studies of future land use in Europe. Agriculture, Ecosystems \& Environment, 114(1), 1-6.

Verburg, P. H., Eickhout, B., \& Van Meijl, H. (2008). A multi-scale, multi-model approach for analyzing the future dynamics of European land use. Annals of Regional Science, 42(1), 57-77.

Verburg, P. H., Van de Steeg, J., Veldkamp, A., \& Willemen, L. (2009). From land cover change to land function dynamics: a major challenge to improve land characterization. Journal of Environmental Management, 90, 1327-1335.

Vonk, G., Geertman, S., \& Schot, P. (2005). Bottlenecks blocking widespread usage of planning support systems. Environment and Planning A, 37, 909-924.

VROM. (2008). PlanMER Structuurvisie Randstad 2040: naar een duurzame en concurrerende Europese topregio. Den Haag: Ministerie van Volkshuisvesting, Ruimtelijke Ordening en Milieubeheer(VROM).

Vullings, W., De Vries, M., \& De Borman, L. (2007). Dealing with uncertainty in spatial planning. 10th AGILE International Conference on Geographic Information Science. Aalborg University, Denmark.

Vullings, L. A. E., Wessels, C. G. A. M., \& Bullens, J. D. (2009). Fuzziness to reduce uncertainty. 12th AGILE International Conference on Geographic Information Science. Leibniz Universität Hannover, Germany.

Wagtendonk, A. J., Julião, R. P., \& Schotten, C. G. J. (2001). A regional planning application of Euroscanner in Portugal. Chapter 18. In J. C. H. Stillwell \& H. J. Scholten (Eds.), Land use simulation for Europe (pp. 257-291). Amsterdam: Kluwer Academic Publishers.

Walter, C., \& Stützel, H. (2009). A new method for assessing the sustainabilty of land-use systems (II): evaluating impact indicators. Ecological Economics, 68(5), 1288-1300. 